\title{
THE CONSTITUTIONALITY OF WARRANTLESS SEARCH AND SEIZURE OPERATIONS
}

by Lehlohonolo January*

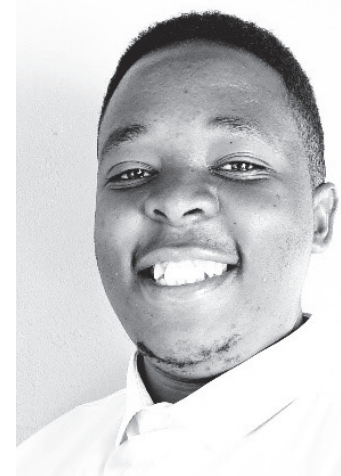

\section{Introduction}

There are various crimes committed in South Africa which have shown an increased rise over the past decade. Most crimes bear the potential to be efficiently combatted through search and seizure operations. According to national crime statistics crimes such as carjacking, illegal possession of firearms and ammunition, drug related crimes and robbery of cash in transit (which in 2018 experienced an increment of $56.6 \%$ increase from 2017) are the crimes which have increased and continue to increase. ${ }^{1}$ The crimes which have been highlighted are gateway crimes through which other subsidiary crimes such as assault, murder, rape and others are committed. ${ }^{2}$ However, it is through the efficient procedure of search and seizure operations that crimes of such a nature have the potential to decrease exponentially.

Search and seizure operations are tools which are designed to help the police carry out their constitutional mandate of 'inter alia' preventing, investigating and combating crime efficiently. Generally, search and seizure operations are required to be conducted within the confines of a search warrant. ${ }^{3}$ A warrant is a legal instrument issued

* LLB: University of the Western Cape; LLM: International Trade Law Candidate, University of Cape Town. ORCID: 0000-0003-4359-1536.

1 SAPS 'National Crime Statistics: Crime situation in RSA twelve months' 1 April 2017 - 31 March 2018 https://www.saps.gov.za/services/long_version_presen tation_april_to_march_2017_2018.pdf (accessed 11 March 2019).

2 M Schonteich \& A Louw 'Crime in South Africa: A country and cities profile' (2001) 49 Crime and Justice Programme, Institute for Security Studies 4. 
by a judicial officer which sets out the scope, reasons and duration with which the police may search, and it ensures that the police do not invade private property for no particular reason. ${ }^{4}$ The search warrant ensures that the State justify and support the intrusion of privacy under oath before an officer of the court prior to the intrusion. 5

South Africa boasts a widespread legislative infrastructure authorising warrantless search and seizure operations. The Criminal Procedure Act, ${ }^{6}$ South African Police Services Act, ${ }^{7}$ the North West Gambling $A c t^{8}$ and the Drugs and Drug Trafficking $A c t^{9}$ are the most commonly used statutes which authorise the police to conduct warrantless search and seizure. However, the empowering provisions of the Drugs Act have recently been repealed after the Constitutional court declared them to be unconstitutional. ${ }^{10}$

It is under the authority granted by section 22 of $\mathrm{CPA}^{11}$ in which a police official may search any person, premises or container with the purpose of seizing any article referred to under section 20 which has been used to commit an offence; may have been intended to be used to commit an offence or may provide evidence for an offence already committed. The origins of this section emanate from the Apartheid regime under whose authority police officials were granted unfettered powers to effectively limit the rights of citizens. ${ }^{12}$ Under this regime powers such as these were abused as they were fundamentally directed at oppressing particular groups of society. ${ }^{13}$ Nevertheless, our nation has since progressed from the rule of the Apartheid government and the dawn of our democracy saw the need to protect the rights which are fundamental to the personal freedoms of individuals.

To avoid unjustified intrusions of ones' property and privacy by police officials the Constitution of the Republic of South Africa, ${ }^{14}$

3 A Price 'Search and seizure without warrant' (2015) 6 Constitutional Court Review 247.

$4 \quad \mathrm{~V}$ Basdeo 'The constitutional validity of search and seizure powers in South African criminal procedure' (2009) 12 Potchefstroom Electronic Law Journal 313.

5 WT Tongoane 'Warrantless Search \& Seizure in terms of the Drugs and Drug Trafficking Act, Criminal Procedure Act and South African Police Services Act: A Comparative Analysis with Canadian Law' unpublished LLM thesis, University of Pretoria, 20175.

6 The Criminal Procedure Act 51 of 1977 (thereafter 'CPA').

7 The South African Police Services Act 68 of 1995 (thereafter 'SAPS Act').

8 The North West Gambling Act 2 of 2001 (thereafter 'Gambling Act').

9 The Drugs and Drug Trafficking Act 140 of 1992 (thereafter 'Drugs Act').

10 See Minister of Police and others v Kunjana $2016 \mathrm{JOL} 36315$ (CC) para 47.

11 CPA (n 6 above) sec 22.

12 N Parpworth 'The constitutional invalidity of warrantless drugs searches in South Africa' (2018) 91(2) The Police Journal: Theory, Practice and Principles 128.

13 Parpworth (n 12 above) 128.

14 The Constitution of the Republic of South Africa, 1996 (thereafter 'the Constitution'). 
under the Bill of Rights affords everyone various rights such as the right to privacy in an attempt to curtail unlawful warrantless search and seizure operations. How successful have such fail-safe mechanisms been in so far as ensuring that certain rights aren't unduly violated? Would the use of less intrusive mechanisms provide the same results gained with the use of search and seizure operations? This research will thus consider whether or not section 22 of CPA is inconsistent with the spirit, purport and object of the Constitution.

To provide a brief overview of this paper; the introduction will illuminate the aim of the research followed by an examination of what constitutes 'search' and 'seizure' in terms of CPA. The paper will thereafter consider the existing jurisprudence on search and seizure operations and elucidate the manner in which search and seizure operations affect certain rights in the Bill of Rights. An examination of search and seizure operations under Canadian law will be conducted with the paper culminating in a conclusion containing recommendations regarding the enforcement of search and seizure operations.

\section{The Criminal Procedure Act ${ }^{15}$}

All warrantless search and seizure provisions are subject to constitutional scrutiny as the Constitution is the supreme law of the country. ${ }^{16}$ If any provision authorising warrantless search and seizure operations is alleged to violate a right in the Constitution, it may be declared constitutionally invalid unless the violation is found to be reasonable and justifiable in an open and democratic society based on human dignity, equality and freedom, taking into account all relevant factors. ${ }^{17}$

Chapter 2 of $\mathrm{CPA}^{18}$ addresses the issuing of search warrants, entering of premises, seizure, forfeiture and disposal of property connected with offences as per sections 19 to 36 . The CPA personifies the general provision with regard to the searching of premises and this is evident from section 19 of CPA, which in essence states that any other legislation which confers the power to search and seize articles does so in tandem with the general provisions of CPA. Following the enactment of the Constitution various mechanisms have been employed both by the Constitution and CPA to restrict the power on warrantless search and seizures. This includes constitutional

15 CPA (n 6 above).

16 The Constitution (n 14 above) sec 2.

$17 \mathrm{Sec} 36(1)$ of the Constitution; See general discussion in $S \vee$ Makwanyane and Another CCT3/94 1995 ZACC 3 (thereafter 'Makwanyane').

18 Search warrants, entering of premises, seizure, forfeiture and disposal of property connected with offences. 
standards as well as reasonable standards against which such powers ought to be measured. The use of such metrics ensures that whenever such powers are exercised, it is such that they are exercised within the parameters of what is acceptable in a democratic society.

\subsection{Articles susceptible to seizure}

The CPA provides set categories of items which may be seized by the State. As such, the scope of the search is limited to only 'where the object of the search is to find a certain person or to seize an article which falls into one of the categories of items ${ }^{19}$ which may be seized by the State. The general rule regarding articles that are susceptible to seizure is that if they fall into sections 20(a) - (c) the State may lawfully seize them, however there is an exception to this rule. Documents that are privileged, to which the holder of the document has not withdrawn his or her privilege may not be seized by the State as this defeats the purpose of exercising privilege over the document. ${ }^{20}$ In SASOL III (Edms) Bpk v Minister van Wet en Orde ${ }^{21}$ it was held that such a document may not be seized by the State. ${ }^{22}$

Normally, at the conclusion of the criminal proceedings it is required that the presiding officer make an order regarding the disposal of the article. The article may either: (a) be returned to the person from whom it was seized; ${ }^{23}$ be returned to the person who is entitled to it and may lawfully possess it, ${ }^{24}$ or if no person may lawfully possess it and the owner is unknown by the police, it is forfeited to the State. 25

\subsection{Search and Seizure}

It is thus vital to establish what constitutes a search and seizure in terms of South African law. The terms 'search' and 'seizure' are not defined by CPA and thus the question of what constitutes a search is left to be sourced from the common law. It is maintained that an element of physical intrusion concerning a person or property is necessary to establish a search. ${ }^{26}$ The term 'search' where it relates to a person must be given its ordinary meaning according to its context. $^{27}$ By extension this would then also apply to the term

19 M Basdeo et al 'Search and seizure' in JJ Joubert (eds) Criminal Procedure Handbook (2017) 178.

20 M Basdeo et al 'Search and seizure' in JJ Joubert (n 19 above) 178.

21 SASOL III (Edms) Bpk v Minister van Wet en Orde 19913 SA 766 (T) (thereafter' SASOL').

22 SASOL (n 21 above) par 772E

23 CPA (n 6 above) sec 34(1)(a).

24 CPA (n 6 above) sec 34(1)(b).

25 CPA (n 6 above) sec 34(1)(c).

26 Basdeo (n 4 above) 310.

27 Basdeo (n 4 above) 310. 
seizure. In Ntoyakhe $v$ Minister of Safety and Security ${ }^{28}$ the court held that the word 'seize' encompasses not only the act of taking possession of an article, but also the subsequent detention thereof, otherwise the right to seize would be rendered worthless. ${ }^{29}$

Considering that both these terms are provided for in section 14 of the Constitution the meaning of these terms should thus also be viewed from a constitutional perspective. Sourcing a definition requires an element of physical intrusion to be present, related to the level of privacy provided for in the Constitution and if there is no reasonable expectation of privacy then no search has occurred. ${ }^{30} \mathrm{~A}$ far clearer understanding can be sourced from JUTA's legal terminology dictionary which defines 'seizure' as 'judicial taking into possession of property'. In this context the term is usually associated with the act of a law enforcement officer in seizing evidence, or contraband, or in attaching property under a writ. ${ }^{31}$

Turning to foreign law for clarity, in Silverman $v$ United States, ${ }^{32}$ heard in the United States the term search is defined as 'a government official's physical touching of a person, or the physical entry into a private area, or the physical handling of papers and effects. 33 Physical intrusion into private areas is inclusive of surveillance devices such as those used for electronic listening, eavesdropping or telescopic observation. ${ }^{34}$ The court went on to define seizures as 'government interference with an individual's liberty or possessory interest and this definition is considered to include both the physically taking of tangible property, and intangibles such as private conversations'. ${ }^{35}$ One is now able to deduce that in order for a search and seizure to be established there needs to be a certain measure of intrusion and depravation of privacy by the State.

\subsubsection{Search and seizure with a warrant}

As briefly mentioned above, it is preferable that search and seizure operations take place in the confines of a search warrant issued by a judicial officer. The procedure of securing a search warrant is governed by section 21 of CPA which states that 'subject to the

28 Ntoyakhe v Minister of Safety and Security 2000 (1) SA 257.

29 Basdeo (n 4 above) 313.

30 Basdeo (n 4 above) 310.

31 MW Prinsloo et al 'Legal terminology: criminal law, procedure and evidence' South African Law Journal (2015), 271.

32 Silverman v United States 81 US (S) 679 (1961).

33 Silverman (n 32 above) 509 - 510.

34 JP Swanepoel, "Warrantless search and seizure in criminal procedure: a constitutional challenge' (1997) 34 The Comparative and International Law Journal of Southern Africa 341.

35 Swanepoel (n 34 above) 342. 
provisions of sections 22,24 and 25 , an article referred to in section 20 shall be seized only by virtue of a search warrant issued by' ${ }^{36} \mathrm{a}$ magistrate or justice of peace who on reasonable grounds believes that any such article is at any premises within his jurisdiction as a result of information provided under oath. ${ }^{37}$

Alternatively, if during criminal proceedings, the judge or judicial officer presiding requires an article as evidence before him or her, a warrant may be issued to bring the required article to court. ${ }^{38}$ The requirement that a search warrant be issued by a judicial officer serves as an objective mechanism to protect individuals from violations of their right to privacy and other fundamental rights as they function independently and exercise their discretion in a judicial manner. ${ }^{39}$ This means that discretion ought to be exercised 'in a reasonable and regular manner, in accordance with the law and while taking all relevant facts into account'. ${ }^{4}$

Additional mechanisms exist to safeguard the rights of the individual as the warrant must clearly define the purpose of the search and the articles that may be seized. ${ }^{41}$ This also safeguards the police from any potential civil liability that might ensue as a result of the search. If a warrant appears to define the articles that may be seized in "broad and general terms" 42 the court will declare that the judicial officer did not apply their mind properly to the question whether there had been sufficient reason to interfere with the liberty of the individual. ${ }^{43}$ To prevent further encroachment on the rights of the individual, a search warrant must be executed by day, unless the judicial officer specifically authorises that it be executed by night. ${ }^{44}$ Collectively these safeguard mechanisms ensure that, should an individual's right to privacy be violated, a legal justification can be offered in response.

\subsubsection{Search and seizure with a warrant}

Section 22 of CPA provides for the circumstances under which articles may be seized without a search warrant. A police official may without a search warrant search any person, container or premises for the purpose of seizing any article referred to in section 20 if: ${ }^{45}$

36 CPA (n 6 above) sec 21(1).

37 CPA (n 6 above) sec 21(1)(a).

38 CPA (n 6 above) sec 21(1)(b).

39 VG Hiemstra 'Introduction to the Law of Criminal Procedure' (1985) 7.

40 Ismael v Durban City Council 19732 SA 362 (N).

41 M Basdeo et al 'Search and seizure' in JJ Joubert (n 19 above) 180.

42 Basdeo (n 4 above) 79.

43 Smith, Tabata \& Van Heerden v Minister of Law and Order 19893 SA 627 (E).

44 CPA (n 6 above) sec 21(3)(a).

45 CPA $n 6$ above) sec $22(\mathrm{a})$-(b). 
(a) the person concerned consents to the search for and the seizure of the article in question, or if the person who may consent to the search of the container or premises consents to such search and the seizure of the article in question; or

(b) he on reasonable grounds believes- (i) that a search warrant will be issued to him under paragraph (a) of section 21 (1) if he applies for such warrant; and (ii) that the delay in obtaining such warrant would defeat the object of the search.

As indicated above, section 22 of CPA clearly allows for police officials to conduct searches with the objective to seize objects without a warrant. Generally, it is preferable that searches should be conducted on the authority of a warrant, however instances may arise where obtaining a search warrant would delay the search and ultimately defeat the purpose of the search. ${ }^{46}$ It is under the ideals of the supremacy of the Constitution as well as the respect for the rule of law that provisions such as section 22 of CPA have undergone judicial scrutiny.

The official in $S \vee$ Motloutsi ${ }^{47}$ conducted a warrantless search and seized certain items hidden in a room occupied by the accused. The official claimed that the search took place in terms of section 22 and that a search warrant could not have been obtained timeously. On the facts of the case the court found that, although a search warrant could not have been obtained without delay from a magistrate, a commissioned officer on duty at the time could have been approached to issue a warrant. The warrantless search amounted to a "conscious and deliberate violation' 48 of the accused's constitutional right to privacy. ${ }^{49}$ The evidence obtained was declared inadmissible.

This judgment clearly indicates that the intrusive nature of search and seizure operations undertone the significant importance and accompanying consequences one needs to remember when electing to engage in warrantless search and seizure operations. The regulation of warrantless search and seizure operations within the criminal justice system is evidence that certain circumstances may arise which require the use of warrantless search and seizure operations, however this must be done within the confines of said legislation's internal limits; failure to do so creates the risk of police officials abusing the powers vested in them. 'Absolving the police from the need to obtain a warrant from the relevant judicial officer creates the real risk that privacy and property rights may be infringed where the circumstances do not merit it.'50

46 Hiemstra (n 39 above) 8.

47 S v Motloutsi 19962 BCLR 220 (C) (thereafter 'Motloutsi').

48 Motloutsi (n 47 above) 230C-D.

49 Motloutsi (n 47 above) 230C-D.

50 Parpworth (n 12 above) 131. 


\section{Case law}

Search and seizure operations together with the legislation and warrants that authorises them often undergo constitutional challenge on the ground that they violate human rights which are of central importance to the individual. The jurisprudence on the issue of search and seizure operations shows that were a right in the Bill of Rights is alleged to have been infringed the judiciary critically analyses the impugned provision(s) with the utmost vigour which is indicative of a judiciary with a high regard for human rights.

In Kunjana the court was faced with the constitutional validity of a warrantless search and seizure operation that took place in terms of sections 11(1)(a) and (g) of the Drugs and Drug Trafficking Act ${ }^{51}$ where a large quantity of drugs and money was found and seized. The section grants police officials the power to conduct a warrantless search on any premises if there are reasonable grounds to suspect that an offence under the Act has or is about to be committed while also granting them the power to seize anything that would result in an infringement of the Act.

The declaration of constitutional invalidity which was initially granted by the Western Cape High Court was subsequently confirmed by the Constitutional Court on the ground that the impugned provision amounted to an infringement on Ms Kunjana's right to privacy in terms of section 14 of the Constitution. ${ }^{52}$ Complying with section 36 of the Constitution the court assessed whether the infringement was justifiable in an open and democratic society and held, inter alia that a rational connection did not exist between the limitation of Ms Kunjana's rights and the purpose of section 11(1)(a) \& (g). ${ }^{53}$ The court also held that officials can prevent and prosecute offences under Drugs Act in a less restrictive fashion than what is contemplated in this section as constitutionally adequate safeguards must exist to justify circumstances where legislation allows for warrantless searches. 54

It should be highlighted that courts have frequently expressed that exceptions to obtaining a warrant should not become the rule. In 2013, the Constitutional Court found provisions in the Customs and Excise $A c t^{55}$ that provided for a warrantless search procedure to unjustifiably conflict with the constitutionally guaranteed right to privacy. ${ }^{56}$ The court stated: "A warrant is not a mere formality. It is a

51 Drugs Act (n 9 above).

52 Kunjana (n 10 above) para 14.

53 Kunjana (n 10 above) para 24.

54 Kunjana (n 10 above) para 30.

55 The Customs and Excise Act 91 of 1964 (thereafter 'Customs Act').

56 Gaertner and others $v$ Minister of Finance and others 200610 BCLR 1133 (CC) (thereafter 'Gaertner'). 
mechanism employed to balance an individual's right to privacy with the public interest in compliance with and enforcement of regulatory provisions. ${ }^{57}$

In 2014, the Constitutional court again found provisions, ${ }^{58}$ which allowed for a warrantless search and seizure procedure unconstitutional because of the limitation on the right to privacy. ${ }^{59}$ It was held by the court that the provisions in question failed to pass constitutional scrutiny primarily because they were premised on searches being conducted without the requirement of a warrant. ${ }^{60}$

In the same year, the Constitutional court found in Ngqukumba $v$ Minister of Safety and Security and others ${ }^{61}$ that the retention of a motor vehicle by the police without having obtained a search and seizure warrant or having acted pursuant to a lawful warrantless search procedure, to be inconsistent with the right to privacy and dignity. ${ }^{62}$ The court held that: ${ }^{63}$

... [i]n the face of the privacy right as well as the right to dignity, which are closely linked, it is not overly restrictive to require of police to comply strictly with search warrant requirements. Where there is a need for swift action, the police can always invoke section 22 of CPA. Strict compliance with the Constitution and the law will not hamper police efforts in stemming the scourge of crime.

The jurisprudence highlighted above clearly shows us that our courts do not overtly favour warrantless search and seizure operation due to the far reaching, often negative consequences they result in; it also does not help that they allow police officials to escape the usual rigours of obtaining a warrant in all cases.

\section{Affected rights}

\subsection{Privacy}

Taking into consideration that a search may infringe upon various rights such as the right to dignity and bodily security, including the protection against cruel, inhuman or degrading treatment, it must be conducted without violating those rights. Initial analysis of the provisions that empower the searching of both persons and premises

57 Gaertner (n 56 above) para 69.

58 Sec 32A of the Estate Agency Affairs Act 112 of 1976 \& sec 45B of the Financial Intelligence Centre Act 38 of 2001.

59 Estate Agency Affairs Board v Auction Alliance (Pty) Ltd \& others 20144 BCLR 373 (CC) (thereafter 'Estate Agency').

60 Estate Agency (n 59 above) para 40.

61 Ngqukumba $v$ Minister of Safety and Security and others 20147 BCLR 788 (CC) (thereafter 'Ngqukumba').

62 Tongoane (n 5 above) 20.

63 Ngqukumba (n 61 above) para 19. 
and the seizing of related articles does seem to go against the spirit and contents of section 12 and 14 of the Constitution, ${ }^{64}$ the right to freedom and security of the person and the right to privacy respectively. Both these rights emanate from and seek to advance the value of human dignity which is one of the core values on which the rights in our Bill of Rights are founded.

It should be borne in mind when electing to engage in search and seizure operations that one would be violating the values that underlie these constitutional provisions which ultimately find their genesis in the context of eighteenth century English common law. ${ }^{65}$ The English society at the time was premised on the notion that the sanctity of the home and the property owner's need to be secure from government intrusion were considered paramount. ${ }^{66}$ The South African Bill of Rights underpins our democracy and espoused in it are the values of human dignity, equality and freedom which are guaranteed to everyone. ${ }^{67}$

However, section 36 of the Constitution reminds us of the 'truism that no right is considered to be absolute and as such implies that from the outset, the interpretation of each right is always already limited by every other right accruing to another citizen' 68 and may accordingly be limited provided that the limitation is reasonable and justifiable. The limitations clause states that 'the rights in the Bill of Rights may be limited only in terms of a law of general application to the extent that the limitation is reasonable and justifiable in an open and democratic society based on human dignity, equality and freedom, taking into account all relevant factors[...]. ${ }^{\prime 69}$ Search and seizure operations will therefore considered to be constitutional if it is authorised by a law of general application, such as CPA. ${ }^{70}$

Given the history of South Africa, with a particular focus on the era of apartheid during which there were constant violations of an individual's right to privacy, it comes as no surprise that the Constitution, under section 14 provides a general right that affords 'everyone [...] the right to privacy'. It is recognised that the right to privacy grants individuals a domain in which they can enjoy their private intimacy and autonomy. In Bernstein the court held that the law recognises a very high level of protection of the individual's intimate personal domain of life and the maintenance of its basic preconditions and that 'there is a final untouchable sphere of human

64 M Basdeo et al 'Search and seizure' in JJ Joubert (n 19 above) 177.

65 Swanepoel (n 34 above) 343.

$66 R$ v Dyment (1988) 45 CCC (3rd) 244 at 253 (thereafter 'Dyment').

67 Basdeo (n 19 above) 4.

68 Bernstein and Others $v$ Bester NO and Others 19962 SA 751 (thereafter 'Bernstein') para 67.

69 The Constitution (n 14 above) sec 36.

70 Basdeo (n 4 above) 4. 
freedom that is beyond interference from any public authority'; with regard to this most intimate core of privacy 'no justifiable limitation thereof can take place'.71

Therefore, the scope of an individual's privacy extends only to those areas in which a legitimate expectation of privacy can be exercised. ${ }^{72}$ The effect of such an interpretation of privacy is that the 'inner core or sanctum' of an individual's life like his or her home, family life and sexual preference is afforded the utmost protection which accordingly decreases as and when an individual moves into communal relations and activities such as business and social interaction which lie at the peripheries of the sanctum of privacy. ${ }^{73}$ As was held in National Coalition for Gay and Lesbian Equality $v$ Minister of Justice that 'we all have a right to a sphere of private intimacy and autonomy which allows us to establish and nurture human relationships without interference from the outside community. The way in which we give expression to our sexuality is at the core of this area of private intimacy. ${ }^{, 74}$

International courts have also grappled with the question of privacy and the extent to which a reasonable expectation of privacy can be harboured and the European Court of Human Rights has pronounced on the issue, holding that telephone calls and e-mails from a business fall under 'private life' and 'correspondence', and as a result are subject to a reasonable expectation of privacy and that monitoring of these communications constitutes a breach of Article 8 of the European Convention on Human Rights. ${ }^{75}$

Drawing on German law, the Constitutional Court of South Africa has adopted the idea of a 'spectrum' or 'continuum' of privacy protection and the notion of 'the sanctum of privacy' no doubt equates to what Sachs $J$ referred to in Mistry $v$ Interim Medical and Dental Council of South Africa ${ }^{76}$ as 'a continuum of privacy which may be regarded as starting with a wholly inviolable inner self, moving to a relatively impervious sanctum of the home and personal life and ending in a public realm where privacy would only remotely be implicated'. 77

71 C Okpaluba, 'Constitutional protection of the right to privacy: The contribution of Chief Justice Langa to the law of search and seizure' (2015) 1 ACTA Juridica 415.

72 W Freedman et al 'Equality, human dignity and privacy rights' in P De Vos (eds) South African Constitutional Law in Context' (2017) 463.

73 Bernstein (n 68 above) para 67.

74 National Coalition for Gay and Lesbian Equality v Minister of Justice 19991 SA 6 (CC) (thereafter 'National Coalition') para 32.

$75 \mathrm{~J}$ Burchell 'The Legal Protection of Privacy in South Africa: A Transplantable Hybrid' (2009) 13.1 Electronic Journal of Comparative Law 1.

76 Mistry v Interim Medical and Dental Council of South Africa 19984 SA 1127 (thereafter 'Mistry').

77 Mistry (n 76 above) para 27. 


\subsection{Human rights}

Another equally important right which is affected by search and seizure operations is the right to human dignity. The Constitution entrenches dignity both as a founding value ${ }^{78}$ which is affirmed throughout our Bill of Rights and as an enforceable right ${ }^{79}$ it is inherently recognised to be afforded to everyone. All of us have a right to privacy together with the broader, inherent right to dignity, collectively they contribute to our humanity. ${ }^{80}$ The right to dignity is understood to implicitly create an expectation to be protected from conditions or treatment which would offend an individual's sense of worth in society. ${ }^{81}$ The pervasive nature of a search has the potential to always violate one's dignity and in order to mitigate such harsh outcomes section 29 of CPA prescribes that a search must be conducted with strict regard to decency and order.

Courts often interpret the right to privacy in conjunction with the right to dignity and as a result concluded that a violation of the former is also a violation of the latter. In Ngqukumba Madlanga J stated that 'in the face of the privacy right as also the right to dignity, which are closely linked, it is not overly restrictive of police to comply strictly with search warrant requirements'.82 This interpretation was again put forward in Gaertner where it was pronounced that 'privacy is most often seen as a fundamental personality right deserving of protection as part of human dignity' ${ }^{83}$ It can thus be deduced that the right to privacy is not protected in isolation, but is further bolstered by the right to dignity and the two rights are often interpreted in tandem.

\section{$5 \quad$ Limitation of rights}

As briefly mentioned above, the Constitution allows for the limitation of all the rights in the Bill of Rights. It allows for any purported conflict in interests between rights contained in the Bill of Rights which stems from a law of general application to be limited in accordance with section 36 of the Constitution, also known as the limitations clause. It is clear from the discussions related to the violation of the right to privacy and the right to dignity mentioned above that the relevant official who is granted the authority to execute a search and seizure operation prima facie violates these

The Constitution (n 14 above) sec 7.

The Constitution (n 14 above) sec 10.

Burchell (n 75 above) 3.

81 W Freedman et al 'Equality, human dignity and privacy rights' in P De Vos (n 72 above) 457.

82 Ngqukumba (n 61 above) para 19.

83 Gaertner (n 57 above) para 86. 
constitutionally entrenched rights. This thus begs the question whether there can be a justifiable limitation on the right to privacy and dignity in terms of section 36 of the Constitution?

Upon reading sections 10 and 14 of the Constitution, which speak to the right to dignity and the right to privacy, respectively, one might be tempted to believe that the sections provide for an absolute right to dignity and privacy. ${ }^{84}$ However, this is not the case as they may be limited, only in terms of a law of general application. Section 36(1) of the Constitution sets out criteria qualifying acceptable restrictions of the rights in the Bill of Rights and the factors to be taken into account when assessing a limitation. ${ }^{85}$

The criteria applied in section 36 is one that requires considerations of what is reasonable and justifiable in an open and democratic society based human dignity, equality and freedom. ${ }^{86}$ When assessing the reasonableness or justification of a limit on any right contained in the Bill of Rights, a court is to give due consideration to the factors listed in section 36(1)(a) to (e) as well as any other relevant factors as a mechanism akin to a checklist when assessing the validity of a limitation. ${ }^{87}$

Madlanga $\mathrm{J}$ in Gaertner held that a warrant is not a mere formality, it guarantees that the state must be able, prior to an intrusion, justify and support intrusions upon an individual's privacy under oath before a judicial officer. ${ }^{88}$ The interpretation of the Constitution, especially provisions such as section 36 , often require one to engage in a delicate balancing act between the rights of the individual and the rights of the State. ${ }^{89}$ Potgieter postulates that '[a]n acceptable [B]ill of [R]ights should ensure a proper balance between individual freedom and state power. Obviously, the state should be prevented from abusing its power. On the other hand, a [B]ill of $[R]$ ights should not render the state powerless to protect law-abiding citizens effectively against their freedom to the detriment of civilised values $[. ..] .^{90}$

When considering who bears the onus of proof it is considered trite law that he who alleges must prove. Therefore, the party that first seeks to establish the existence or violation of a particular right,

84 Parpworth (n 12 above) 127

85 Swanepoel (n 34 above) 347.

86 The Constitution (n 14 above) sec 36(1).

87 Parpworth (n 12 above) 128.

88 Gaertner (n 57 above) para 69.

89 Swanepoel (n 34 above) 347.

90 JM Potgieter 'The role of law in a period of political transition: the need for objectivity' (1991) 54 Journal of Contemporary Roman-Dutch Law 806. 
bears the onus of proof and the party that seeks to limit that right bears the onus to justify the limitation in terms of section 36(1). ${ }^{91}$

Park-Ross v Director: Office Serious Economic Offences ${ }^{92}$ clearly elaborated on the requirements that had to be satisfied in order to discharge the onus to justify a limitation in accordance with section 36(1). In this particular case, it was declared by the court that section 6 of the Investigation of Serious Offences Act, ${ }^{93}$ which authorises search and seizures without prior judicial authorisation to have been in violation of the right to privacy in section 13 of the interim Constitution Act. ${ }^{94}$

The Park-Ross ratio makes use of an analogous limitation clause contained in section 1 of the Canadian Charter of Rights and Freedoms $^{95}$ as put forward in $R v$ Oakes. ${ }^{96}$ Much to the courts approval, the court cited and applied the dictum from Oakes in so far as it stated that ' $[\mathrm{t}] \mathrm{o}$ establish that a limit is reasonable and demonstrably justified in a free democratic society, two central criteria must be satisfied. First, the objective, which the measures responsible for a limit on a Charter right or freedom are designed to serve, must be 'of sufficient importance to warrant overriding constitutionally protected right or freedom'. Secondly, once a sufficiently significant objective is recognised, then the party invoking section 1 must show that the means chosen are reasonable and demonstrably justified. ${ }^{97}$ This involves a form of proportionality test. The nature of the proportionality test is such that it will differ depending on the circumstances of the case however, in each case courts will be required to balance the interests of the community with those of the individual despite being applied and approved in many legal systems. The test received approval from the Constitutional Court in Makwanyane. ${ }^{98}$

The three components to the proportionality test are, first, the measures taken must be rationally connected to the objective and should not be arbitrary or based on irrational considerations. ${ }^{99}$ Secondly, the means should impair as little as possible the right or freedom in question. ${ }^{100}$ Thirdly, there must be proportionality

91 Cf Qozeleni v Minister of Law and Order 19942 SACR 340 (EC) (thereafter 'Qozeleni') as approved in S $v$ Zuma and Others 19951 SACR 568 (CC) (thereafter 'Zuma').

92 Park-Ross v Director: Office Serious Economic Offences 19952 SA 148 (C) at 167D-H (thereafter 'Park-Ross').

93 Investigation of Serious Offences Act 117 of 1991 (thereafter 'Serious Offences Act').

94 Interim Constitution Act 200 of 1993 (thereafter 'interim Constitution').

95 Part I of the Constitution Act,1982 (thereafter 'Constitution Act').

$96 R$ v Oakes (1986) 1 SCR 103 (3rd) 321 (SCC) (thereafter 'Oakes').

97 Swanepoel (n 34 above) 349.

98 Makwanyane (n 17 above) para 104.

$99 R$ v Big M Drug Mart Ltd (1985) 1 SCR 295 (3ed) 385 (thereafter 'Drug Mart').

100 Drug Mart (n 99 above) n50 at 167D - H. 
between the effects of the measures which are responsible for limiting the Charter right or freedom and the objective which has been identified as of sufficient importance. ${ }^{101}$ Upon analysis of the criteria laid out in Oakes, one can draw similarities between the due considerations courts are to give to the factors laid out in section 36(1)(a) to (e) and those discussed in the Oakes dictum. The Constitutional Court was initially rather unwilling to adopt the criteria set out in Oakes, ${ }^{102}$ nonetheless, the court did however come to accept that the criteria may offer a certain measure of assistance to our courts and guide the manner in which section 36 of the Constitution should be interpreted. ${ }^{103}$

\section{Canadian law}

Prior to 1982, the law of search and seizure in Canada was a combination of statutory provisions and common law rules relating to search, seizure and police powers. ${ }^{104}$ The harsh reality was that evidence obtained through illegality or impropriety by the authorities was nonetheless admissible in criminal proceedings. ${ }^{105}$ Since 1982 , there have been many positive developments regarding the law of search and seizure; some of these developments have come as a result of decisions by the Supreme Court of Canada and others have consisted of statutory responses by the federal and provincial governments to Charter jurisprudence. ${ }^{106}$ As a result Canada has emerged as a nation that champions legal principles that are based on the values of liberty, dignity, equality and freedom.

The enactment of the Canadian Charter in 1982 brought about significant changes in the content and protection of individual rights. This has been particularly true in respect of the legal rights contained in sections 7 to 14 of the Charter. ${ }^{107}$ However, section 8 is of particular importance as it shields everyone from irrational search and seizures. ${ }^{108}$ In Canada, search and seizure operations are regulated by the Criminal Code of Canada. ${ }^{109}$ The Criminal Code of Canada grants authority to conduct search and seizure operations in respect of certain stipulated offences. Considering the vague wording used in section 8 one might interpret the section as allowing for intrusion that is considered reasonable however the Supreme Court of

101 Drug Mart (n 99 above) n50 at 167D - H.

102 Zuma (n 91 above) para 35.

103 Makwanyane (n 17 above) para 110.

104 T Quigley 'The Impact of the Charter on the Law of Search and Seizure' (2008) 40 The Supreme Court Law Review: Osgoode's Annual Constitutional Cases Conference 117.

105 Tongoane (n 5 above) 30.

106 Quigley (n 104 above) 118.

107 Quigley (n 104 above) 117.

108 The Constitution Act (n 95 above) sec 8.

109 Criminal Code of Canada 1985 c. C-46 (thereafter 'Criminal Code'). 
Canada views the right to privacy as being 'at the heart of liberty in a modern state'. ${ }^{110}$ It is thus imperative to illustrate the context of the terminologies used in section 8 .

\subsection{Search}

A search is said to be any intrusion other than arrest upon an individual's person, property or privacy for the purpose of seizing individuals or things or obtaining information by inspection or surveillance. ${ }^{111}$ Once a form of examination by government begins to intrude upon a reasonable expectation of privacy, is it considered to qualify as a search under the Canadian Constitution. ${ }^{112}$

\subsection{Seizure}

Seizure was defined in Dyment as 'the taking of a thing from a person by a public authority without that person's consent'. ${ }^{113}$ A seizure also includes compelling a person to give up an item. This type of seizure usually occurs in the regulatory field where documents are ordered to be produced. ${ }^{114}$

Much of the framework for analysing section 8 can be derived from Hunter $v$ Southam ${ }^{115}$ and $R v$ Collins, ${ }^{116}$ which are still regarded as the principle authority regarding search and seizures. The relevant principles formulated by these two cases are as follows: the purpose behind section 8 is to protect the privacy of individuals from unjustified state intrusions; this interest in privacy is, however, limited to a 'reasonable expectation of privacy'. ${ }^{117}$ When interpreting the rights in the bill of rights, the South African Constitution allows for the courts to consider foreign law which has provided much guidance in the development of human rights. Canadian jurisprudence has had quite significant influence over South African courts, ${ }^{118}$ therefore it comes as no surprise that both South Africa and Canada entrench the right to privacy and all search and seizure operations must be conducted while adhering to one's right to privacy. A lesson that can be drawn from Canadian jurisprudence with regards to search and seizure operations would be to clearly define the terms 'search' and 'seizure' so as to provide legal certainty when interpreting search and seizure provisions. Both countries do however

110 Basdeo (n 19 above) 321.

111 Basdeo (n 19 above) 322.

112 Quigley (n 104 above) 129.

113 Dyment (n 66 above) para 26.

114 Quigley (n 104 above) 127.

115 Hunter $v$ Southam (1984) 41 CR (3d) 97 (SCC) (thereafter 'Hunter').

$116 R \vee$ Collins (1987) 56 CR (3d) 193 (SCC) (thereafter 'Collins').

117 Quigley (n 104 above) 142.

118 Tongoane (n 5 above) 39. 
protect all against arbitrary intrusion and abuse of power by the police. This is characteristic of nations' that value freedom, liberty and human dignity.

\section{Conclusion and recommendations}

By their nature warrantless search and seizure operations are very unpredictable and can be unreasonable because they gravely diminish one's constitutional rights. The opposite is true when one takes into consideration the high rate of crime and the effective measures needed to combat crime. However, there are many ways in which police officers can be effective in their fight against crime. The laws authorising search and seizure operations must comply with the constitutionally entrenched right to privacy, ${ }^{119}$ as the constitutionalism project necessitates that citizens should be shielded from unjust intrusions of their right to privacy at the hands of the state. ${ }^{120}$ Failure to provide this shield could lead to the prejudicial treatment of citizens' personal freedoms and it has been contended that 'uncontrolled search and seizure is one of the first and most effective weapons in the arsenal of every arbitrary government.'121

It would be unfair to characterise the nascent South African democracy of being arbitrary as in the context of criminal justice the search and seizure of an article is considered justified for the purposes of: confiscation because their possession is unlawful, ${ }^{122}$ to return the article to its rightful owner, ${ }^{123}$ for evidential material in a prosecution, ${ }^{124}$ and to be forfeited to the state if they were used in the commission of a crime. ${ }^{125}$ Prior judicial authorisation and objective grounds for a search are considered safeguards to ensuring the reasonableness of a search in South African law as well as in Canada and the United States of America. ${ }^{126}$

The Constitutional court has created a consistent chain of authority regarding the constitutionality of search and seizure operations in Ngqukumba, Gaertner, Estate Agency Affairs Board and Kunjana therefore, it would be minded that Parliament going forward, align all other pieces of legislation which regulate warrantless search and seizure operations with the principle

119 Okpaluba (n 71 above) 429.

120 Basdeo (n 19 above) 323.

121 Brinegar $v$ United States 338 US 160 at 180 (1949).

122 CPA (n 6 above) sec 31.

123 CPA (n 6 above) sec 30(b).

124 CPA (n 6 above) sec 20(b).

125 CPA (n 6 above) sec 35.

126 Basdeo (n 19 above) 323. 
legislation on warrantless search and seizure operations, section 22 of CPA.

Any law that doesn't comply with the internal restrictions provided by CPA should be amended so that there is greater clarity on the powers conferred to police officers and those authorised to execute search and seizure operations. The endorsement of section 22 of CPA is in line with the approval it has received by the Constitutional court in Gaertner and Kunjana rather than Parliament running the risk of further legislation being found unconstitutional and invalid. Clarity defines and protects the interests of all parties to the process and is more easily and cheaply achieved through legislation rather than court cases. ${ }^{127}$ 